\title{
Богословско-экзегетический разбор воскресного догматика Великой вечерни 1-го гласа
}

\author{
прот. Владимир Петручик \\ Chrześcijańska Akademia Teologiczna w Warszawie, Polska \\ ORCID: 0000-0002-7710-783X \\ rambulik@mail.ru
}

Petruchik V., Theological exegetical analysis of the Great Vespers Sunday dogmatic of the 1st tone, Elpis, 23 2021: 29-39.

Petruchik V., Teologiczno-egzegetyczna analiza niedzielnych dogmatyków Wielkiej wieczerni 1-go tonu, Elpis, 23 2021: 29-39.

\begin{abstract}
A dogmatic is a short chant of dogmatic content devoted to the Holy Virgin. According to the orthodox tradition, the author of dogmatics is considered reverend John Dam-askin (VII cent.). Due to their poetic style and form, structural specificity and contents dogmatics are the best proof that our church hymn writing is a church confession of our dogmata, our teaching of faith and morality. Listening to these enlightening chants dur-ing church service plunges Christians into the impenetrable depth of our faith.
\end{abstract}

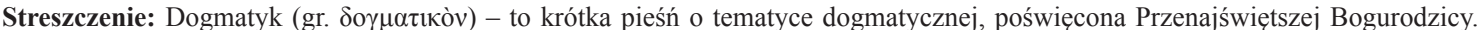
Według prawosławnej tradycji za ich autora uważany jest święty Jan z Damaszku (VIII wiek). Dzięki swojemu poetycznemu stylowi, formie, budowie oraz treści dogmatyki są najlepszym dowodem na to, że nasza cerkiewna hymnografia jest świątynnym wyznaniem naszych dogmatów, nauki wiary oraz nauki moralności. W taki sposób podczas uważnego wsłuchiwania się w te pouczające pieśni, chrześcijanin w trakcie nabożeństwa wnika w mistyczne głębiny naszej wiary.

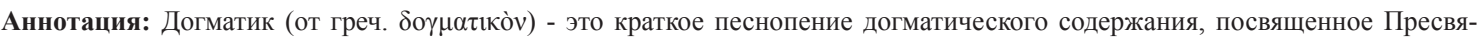
той Богородице. Согласно православной традиции автором догматиков считают преподобного Иоанна Дамаскина (VIII век). Благодаря своему поэтическому стилю и форме, особенности построения и содержанию, догматики служат лучшим подтверждением того, что наша церковная гимнография - это храмовое исповедание наших догматов, нашего вероучения и нравоучения. Таким образом, при внимательном слушании этих поучительных песнопений христианин за богослужением посвящается в таинственные глубины нашей веры.
\end{abstract}

Keywords: theology, dogmatic, the Incarnation of God ,Theotokos

Slowa kluczowe: teologia, dogmatyk, Wcielenie Boga, Bogurodzica

Ключевые слова: богословие, догматик, Боговоплощение, Богородица

\section{1. Введение}

«Церковные молитвословия содержат в себе пространное христианское догматическое и нравственное богословие: посещающий неупустительно церковь и тщательно внимающий ее чтению и песнопению может отчетливо научиться всему нужному для православного христианина на поприще веры» (Svt. Ignatij Brânčaninov, 2001, s. 165). Эти слова свт. Игнатия Брянчанинова, рожденные его богатым духовным опытом, подводят итог размышлениям святого о важности и необходимости посещения верующими православного богослужения. Действительно, Православная Церковь, как говорит свт. Ириней Лионский, - это «богатая сокровищница», в которую «апостолы в полноте положили все, что принадлежит истине, так что каждый желающий может принимать от нее питие жизни» (Svt. Irinej Lionskij, 1895, s. 118). Поэтому, если Православная Церковь является сокровищницей истины, то хранимое в ней сокровище истины бесценно само по себе, а это значит, что каждый молящийся, каждый, кто находится на богослужении, призван молиться с осо- бым вниманием, погружая свой ум в слова молитвы и стараясь проникнуть в смысл текстов, произносящихся в храме. Причем понимание богослужебных текстов и внимательность на богослужении одинаково важно и необходимо как для священнослужителей, для которых течение богослужения уже привычно и знакомо, так и для мирян, которые не всегда имеют достаточного духовного и практического опыта.

Но, если молитвы и песнопения святым, а также прославленным и почитаемым иконам Богородицы, составленные в период новейшей истории нашей Церкви, близки нашему сердцу и редко вызывают непонимание в нашем уме, то молитвословия двунадесятым и великим праздникам, совершаемым с древних времен, тексты Октоиха, Постной и Цветной Триоди и других богослужебных книг представляют для нас определенную трудность. Трудность состоит в том, что все эти тексты являют собой древние памятники Византийской литургической поэзии, переведенные на славянский язык много столетий назад, и поэтому разобраться в их содержании и смысле, не владея языком оригинала, не зная законов византийской поэтики, весьма затруд- 
нительно. Единственный способ не остаться в стороне от богослужебной красоты и приобщиться к богатствам литургической поэзии Православной Церкви - это систематическое ее изучение, подобно тому, как изучают музыку, математику или другие науки. Но изучать богослужебные тексты можно несколькими способами. Например, можно ежедневно ходить в храм и следить по книгам за тем, что там поется и читается, или, например, человек может и сам, если он обладает к этому соответствующими способностями и талантами, читать и петь на клиросе. Если человек располагает свободным временем, то он может изучать богослужебные тексты в спокойной обстановке дома. Все перечисленные способы однозначно полезны, но полезны каждый по-своему. Но есть еще один способ, более эффективный и полезный - изучать греческий и славянский языки и сравнивать оригинальный текст со славянским переводом.

Настоящая работа является попыткой путем сравнения греческого и славянского текстов явить подлинный и глубинный смысл воскресного догматика Великой вечерни 1-го гласа.

\section{2. Текст воскресного догматика великой вечерни 1-го гласа}

Приведем текст воскресного догматика великой вечерни 1-го гласа:

«Всемирную славу от человек прозябшую и Владыку рождшую, Небесную дверь воспоим, Марию Деву, Безплотных песнь и верных удобрение: Сия бо явися небо и храм Божества; Сия преграждение вражды разрушивши, мир введе и Царствие отверзе. Сию убо имуще веры утверждение, Поборника имамы из Нея рождшагося Господа. Дерзайте убо, дерзайте, людие Божии, ибо Той победит враги, яко Всесилен» (Oktoih, 1981, s. 14).

Теперь для сравнения и изучения возьмем этот же текст на греческом языке:

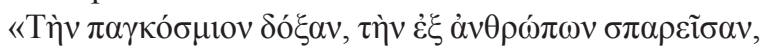

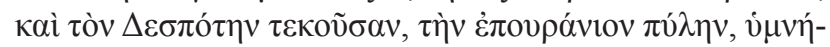

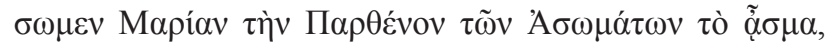

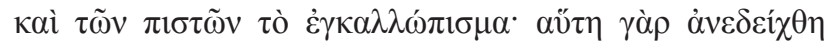

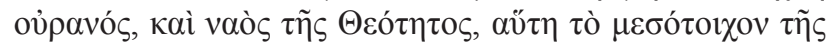

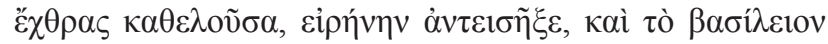

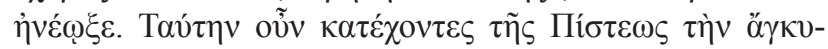

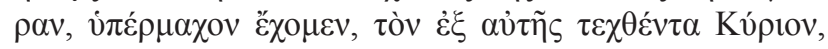

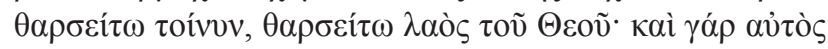
$\pi \circ \lambda \varepsilon \mu \eta \dot{\sigma \varepsilon 1, ~ \tau o v ̀ \varsigma ~ \varepsilon ̇ \chi \theta ~}$

\section{1 Структура догматика}

При внимательном изучении догматика можно заметить, что он имеет следующую структуру.

В первой его части преп. Иоанн Дамаскин призывает верующих «воспеть» Марию Деву:

«Всемирную славу,

От человек прозябшую,
И Владыку рождшую,

Небесную дверь

Воспоим Марию Деву -

Безплотных песнь

И верных удобрение!».

Далее автор догматика перечисляет те причины, по которым следует воспевать и славить Пресвятую Богородицу:

«Сия бо явися

Небо и храм Божества;

Сия преграждение

Вражды разрушивши, Мир введе

И царствие отверзе,

Сию убо имуще

Веры утверждение,

Поборника имамы

Из нея рождшагося Господа».

И, наконец, догматик заканчивается горячим духовным призывом:

Дерзайте убо,

Дерзайте, людие Божии!!

Ибо Той победит враги,

Яко всесилен.

\section{2 Богословско-экзегетический разбор первой части догматика}

\author{
«Всемирную славу, \\ От человек прозябшую, \\ И Владыку рождшую, \\ Небесную дверь \\ Воспоим Марию Деву - \\ Безплотных песнь \\ И верных удобрение!»
}

С первых строк своего догматика преп. Иоанн Да-

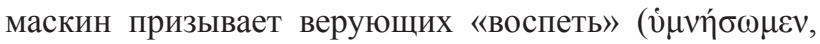
в переводе с греч. - «воспевать», «торжественно петь», «прославлять в песнях», «объявлять», «провозглашать») (Vejsman, 1900, s. 1270) Пресвятую Богородицу, Которую автор догматика именует «всемирной славой», «небесной дверью», «безплотных песнь», «верных удобрение».

Для того чтобы понять, почему автор привел эти сравнения, какую любовь и благоговение он вложил в каждое из этих Богородичных наименований, какие внутренние сердечные переживания овладевали автором, необходимо эти слова вступления прочитать сквозь призму жития самого преподобного. Согласно житийным описаниям преп. Иоанн родился в 676 году в г. Дамаске, столице Сирии, в семье Сергия, который на тот момент исполнял должность министра при дворе дамасского халифа. В виду занятости отца, воспитанием младенца занимался пленный инок Косьма, который в будущем станет известным для нас, как епископ Маиумский. Вскоре высокое положение отца и личные качества его сына способствовали тому, что через некоторое время Иоанн был поставлен градоначальником 
г. Дамаска и первым министром халифа. Но, находясь при дворе халифа, окруженный пышностью и почетом, Иоанн всем сердцем стремился «в безмолвии работать Богу» (Arhiep. Dimitrij (Rostovskij), 1906, s. 99). В 728 году император Лев объявил открытое гонение на защитников и почитателей икон. Выступая за иконопочитание, Иоанн написал немало сочинений в защиту святых икон, чем и вызвал против себя гнев императора. Оклеветанный в неверности халифу, Иоанн был подвергнут отсечению руки, которая была исцелена по его слезной молитве перед образом Пресвятой Богородицы. Но, невзирая на то, что невиновность Иоанна была полностью доказана, он не пожелал далее оставаться при дворе. Раздав все имущество бедным и даровав свободу всем своим рабам, Иоанн удалился в Иерусалимскую обитель святого Саввы. Но и здесь его испытания не закончились. За нарушение благословения старца, запретившему иноку Иоанну всякий вид литературной деятельности, преподобный своими руками очистил все нечистоты в обители. Здесь уже и сам старец был вразумлен явлением Пресвятой Богородицы, указавшей ему, каким благодатным сосудом для Церкви Христовой является Иоанн. С тех пор, как отмечает в своем труде об отцах Церкви свт. Филарет Черниговский, преподобный стал свободно «писать и петь во славу Православия» (Arhiep. Filaret Gumilevskij, 1882, s. 197).

Это краткое описание духовного возрастания преп. Иоанна Дамаскина помогает нам раскрыть его личность как песнописца. Ведь надо понимать, что те эпитеты, образы, метафоры и сравнения, которые он употребляет в своем гимнографическом творчестве по отношению к Божией Матери, это не просто поэтические приемы и показатель художественного мастерства автора. Эти слова идут из глубины сердца. Сама жизнь автора родила эти слова, чтобы, по справедливому замечанию монахини Игнатии, «его песнопения вместили по возможности все глубины человеческой скорби и изобразили выход из нее в Едином Спасающем - Боге» (Shimon. Ignatiâ Puzik, 2005, s. 30).

Стоит обратить внимание на славянское словосочетание «от человек прозябшую», которое в греческом

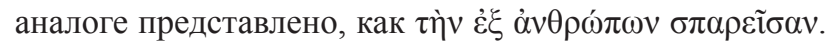
В переводе со славянского языка слово «прозябать» означает «произрастать», «производить», «рождать» (Svâs. Grigorij D'âčenko, 1993, s. 508). При произнесении слова «прозябать» каждому церковно-образованному человеку на ум сразу приходит параллель с историей из Ветхого Завета о прозябшем жезле Аарона: «И бысть на утрие, и вниде Моисей и Аарон в скинию свидения: и се, прозябе жезл Ааронь в дому левиине, и израсти ветвь, и процветоша цвети, и израсти орехи» (Чис. 17; 8). Т.е., согласно значению церковно-славянского словаря, жезл Аарона как бы возродился, получил новую жизнь, поэтому далее он дал ростки и расцвёл миндалевидным деревом, что, как мы видим из дальнейшей Ветхозаветной истории, стало проявлением «суда Божьего» и послужило признаком богоизбранно- сти левитов в их священном назначении. Поэтому славянское словосочетание «от человек прозябшую» можно объяснить тем, что Дева Мария «от людей рождена» или «от людей произошла». Да, действительно, согласно церковному преданию, Дева Мария родилась в галилейском городе Назарете от благочестивых родителей Иоакима и Анны. Иоаким происходил из рода царей, а Анна была дочерью первосвященника. Эти сведения мы получили из Церковного Предания, одного из источников нашего вероучения, наряду со Священным Писанием, поэтому эти факты ни у кого не вызывает никакого сомнения. Но такое объяснение словосочетания «от человек прозябшую» будет очень простым и поверхностным, т.к. смысл его намного глубже.

Чтобы это понять, необходимо проследить и сравнить употребление греческого эквивалента славянского слова «прозябшую» в догматике - бларєі̃ $\alpha \nu$ - с примерами из книг Священного Писания. В Книге Чисел мы читаем: «И бысть на утрие, и вниде Моисей и Ааронь в скинию свидения: и се, прозябе жезл Ааронь в дому Левиине, и израсти ветвь, и процветоша цвети, и израсти орехи» (Чис. 17; 8). Как мы видим, в этом тексте Священного Писания употребляется одинаковое с догматиком славянское слово «прозябе», но в греческом переводе этой цитаты Ветхого Завета такой схожести

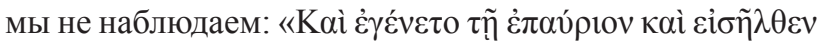

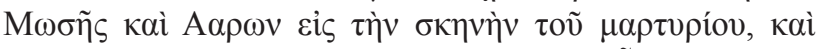

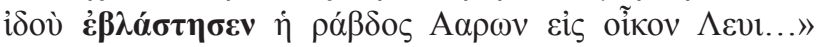

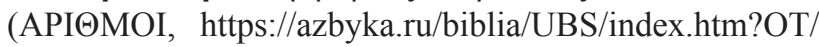
$\mathrm{Nu}$ ? 17, 11. 03. 2019). Итак, перед нами одно славянское слово «прозябать», которое имеет два греческих экви-

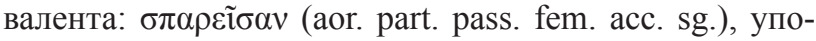
требляющееся в догматике со значением «сеять или сажать», «засевать», «обсеменять», «оплодотворять», «производить на свет», «(по)рождать», «рассеивать», «разбрасывать», «рассыпать», «наливать», «поливать», «распространять», «расточать» (Vejsman, 1899, s. 1144),

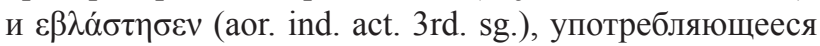
в Книге Чисел со значением «проросла», «возникать», «рождаться», «происходить» (Vejsman, 1899, s. 360). Как мы видим, два совсем разных греческих слова, и соответственно можно предположить, что и два совсем разных значения.

Приведу другой пример употребления греческого

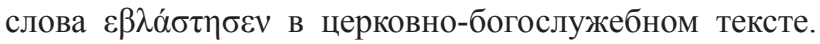
Во вторник первой седмицы Великого Поста на 2 - ой песни канона мы читаем: «Неоранная земле, прорастившая всех Питателя, отверзающаго руку, и благоволением Своим насыщающа всякое животное крепостию Божественною: утверди хлебом жизненным, ослабевшая сердца сытостию лютых наших прегрешений» (Postnaâ Triod', 1992, s. 96). В греческом аналоге этого текста мы вновь встречаем синоним слова

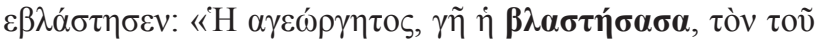

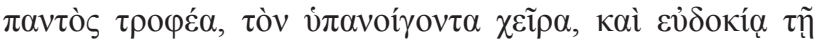

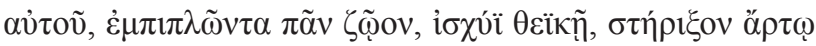

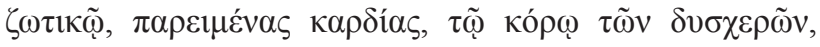




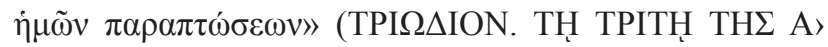
EB $\triangle \mathrm{OMA} \Delta \mathrm{O} \Sigma, \quad$ http://glt.goarch.org/texts/Tri/t47.html, 12.03.2019).

Теперь таким же образом проанализируем приме-

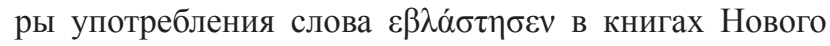
Завета. Евангелие от Матфея: «Егда же прозябе $(\dot{\varepsilon} \beta \lambda \alpha ́ \sigma \tau \eta \sigma \varepsilon v)$ трава и плод сотвори, тогда явишася и плевелие» (Мф. 13: 26), Евангелие от Марка: «И спит,

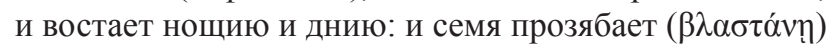
и растет, якоже не весть он» (Мк. 4: 27).

Все эти примеры показывают частое употребление слова $\varepsilon \beta \lambda \alpha ́ \sigma \tau \eta \sigma \varepsilon v$ и производных от него в церковных текстах. В переводе на славянский язык эти греческие слова переводятся словом «прозябать» со значением «прорастать» или точнее «произрастать» и имеют оттенок, как бы, физического получения жизни, жизнь передается от одного к другому. Например, жезл Аарона был засохшим, т.е. не имеющим в себе соков жизни, но Бог его оживил, травы не было, но она появилась, Иисуса Христа не было, но Его произрастила, т.е. явила на свет Дева Мария и т.д. Стоит отметить, что такой же смысл можно найти и в самом слове «прозябать», ведь корень слова «зяб» в переводе с праславянского означает «кол», т.е. наши предки, как опытные земледельцы, прекрасно понимали, что росток, прозябая-вырастая, как бы прокалывает, пробивает почву и появляется на свет.

Теперь обратим свое внимание на греческое слово

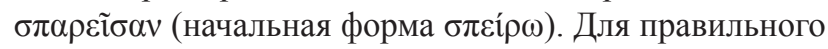
понимания смысла этого слова приведу выдержку из книги «Трактаты и гимны» митрополита Синезия Киренского: «Единый Источник, единый Корень! Просияла форма Трисветлого! Ибо там же, где бездна Отца, там же и славный Сын - некое Порождение [отчего] сердца, космотворящая Мудрость, и там же единящий Свет просиял Святого Духа. Единый Источник, единый Корень поднял богатство благ посредством Своего сверхсущего Отпрыска, в Котором кипят породительные порывы. Своим Светом Он пролагает путь наружу свету блаженных удивительных существ, пребывающих в [сфере] сущности, от которых происходит уже и внутрикосмический хор бессмертных царей, воспевающих в гимнах славу умным [существам], и первосеменной эйдос. Близ своих благожелательных родителей войско ангелов, не знающих старости: они то взирают в Ум, сбирая начало красоты, то - глядя на круговращения [звездных сфер] - управляют глубинами [дольнего] космоса, увлекая космос горний с [умопостигаемых] высей к пределам материи, где оседающая природа рождает толпы демонов многошумных и многохитрых. Отсюда же и герои, отсюда и Дух, разлитый (бларє) окрест Земли и оживляющий земные части многоискусными формами» (Mitr. Sinezij Kirenskij, 2012, s. 238). В греческом оригинале на месте слова «разлитый» стоит слово бларєı (Mitr. Sinezij Kirenskij, 2012, s. 566), который является аористом от блєі́р «оплодотворять», «осеменять» (Vejsman, 1899, s. 1144).
Митрополит Синезий Киренский был представителем Александрийской школы неоплатонизма. В данных словах он объясняет образ рождения Пресвятой Троицы, Которая происходит из одного корня. Образ излияния демонстрируется происхождение и истечением третьей Ипостаси от Второй, а Второй - от Первой.

Теперь разберем примеры употребления слова $\sigma \pi \alpha \rho \varepsilon \tilde{\sigma} \alpha v$ и производных от него в книгах Священного Писания. Евангелие от Матфея: «Воззрите на птицы небесныя, яко не сеют (блві́povбเv), ни жнут, ни собирают в житницы, и отец вашъ небесный питает их. Не вы ли паче лучши ихъ есте?» (Мф. 6: 26), «и глагола им притчами много, глаголя: се, изыде сеяй (блєі́р

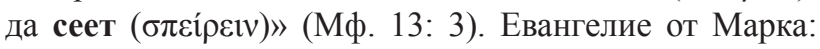
«И бысть егда сеяше (блєі́рєเv), ово паде при пути, и приидоша птицы, и позобаша е» (Мк. 4: 4), «и сии

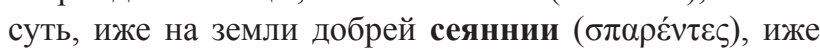
слышат слово и приемлют, и плодствуютъ на тридесять, и на шестьдесят, и на сто» (Мк. 4: 20). Послание к Галатам: «Не льститеся: Бог поругаемь не бывает. Еже

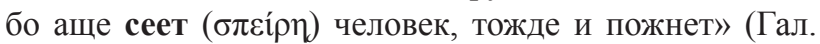
6: 7). Можно продолжать приводить примеры, но вывод будет один: греческое слово бларєіб $\alpha \nu$ имеет оттенок появления не как факт, как мы это проследили на примере слова $\varepsilon \beta \lambda \alpha ́ \sigma \tau \eta \sigma \varepsilon v$, а сам процесс подготовки к появлению, наполнение внутренней силой, оплодотво-

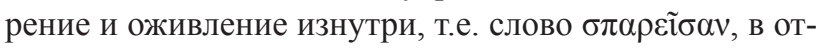
личии от слова $\varepsilon \beta \lambda \alpha ́ \sigma \tau \eta \sigma \varepsilon v$, указывает на длительность процесса.

Таким образом, несмотря на то, что греческие слова $\sigma \pi \alpha \rho \varepsilon \tilde{\sigma} \alpha \nu$ и $\varepsilon \beta \lambda \alpha \dot{\sigma} \sigma \eta \sigma \varepsilon v$ переводятся на славянский язык одним словом «прозябшую», смысл их совершенно разный. И это различие помогает нам понять смысл словосочетания «от человек прозябшую» в догматике преп. Иоанна Дамаскина.

Да, действительно, факт рождения Пресвятой Богородицы действительно неоспорим. В честь этого события в Церкви был установлен двунадесятый праздник. Рождение Марии было великой радостью и утешением не только для праведных Иоакима и Анны. Их радость можно понять, ведь бездетность была их личной скорбью и вызывало общественное порицание. Но, кроме личного семейного счастья, рождение Марии было радостью для всей Вселенной. Это не просто радостное событие некой иудейской пары, это событие вселенского масштаба. Именно так мы поем в тропаре этого праздника: «Рождество Твое, Богородице Дево, радость возвести всей вселенней: из Тебе бо возсия Солнце правды Христос Бог наш, и, разрушив клятву, даде благословение, и, упразднив смерть, дарова нам живот вечный» (Mineâ, sentâbr', 1997, s. 236). Именно эту мысль и пытается донести до нас преп. Иоанн

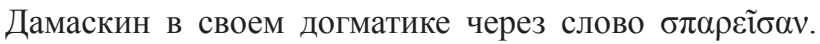
Дева Мария явилась не просто плодом соития Ее родителей, Она стала плодом многовековой истории еврейского народа, плодом духовных подвигов лучших его представителей. События рождения Пресвятой Богородицы, как бы, созревали, набирали в себе силу 
на протяжении всей Ветхозаветной истории. Ее образ постепенно раскрывался через прообразы «лествицы Иакова» (Быт. 28: 12-16), «неопалимой купины» (Исх. 3: 2), «чудесного перехода через Чермное море» (Исх. 14), «сосуда с Небесной манной» (Чис. 11: 7), «руна Гедеона» (Суд 6: 37-40), пока, наконец, ветхозаветный евангелист Исаия пророчески не возгласил: «Се, Дева во чреве приимет и родит Сына, и нарекут имя Ему: Еммануил» (Ис. 7: 14). На протяжении всего этого долгого времени каждый человек маленькую частичку своего доброго подобно зерну передал Марии, которое в Ней проросло и, как из нитей разного цвета создается красивый ковер, так и все самое лучшее, что могло передать человечество, создало наиболее чистейшее, наиболее смиреннейшее существо, каким явилась Пресвятая Богородица. В своей беседе протопресвитер Александр Шмеман очень точно говорит, что в праздник Рождества Богородицы «мы празднуем и все то и всех тех, которые как бы подготовили Марию, наполнили Ее этой благодатью и красотой...Церковь тоже верит в наследственность, но духовную. Сколько веры, сколько добра, сколько поколений людей, живших высшим и небесным, нужно было, чтобы на древе человечества вырос этот изумительный и благоуханный цветок - пречистая Дева и всесвятая Мать!» (Šmeman, 1993, s. 254). Эта мысль подчеркивается и в стихире навечерия праздника Рождества Христова: «Что Тебе принесем, Христе, яко явился еси на земли яко Человек нас ради? Каяждо бо от Тебе бывших тварей благодарение Тебе приносит: Ангели - пение; небеса - звезду; волсви - дары; пастырие - чудо; земля - вертеп; пустыня - ясли; мы же - Матерь Деву. Иже прежде век, Боже, помилуй нас» (Mineâ. Dekabr'. 1997, s. 492). И, в довершение всех слов, приведу слова свт. Григорий Паламы, который сказал, что величие, святость и чистота Девы Марии - это «результат последовательных очищений, совершавшихся на протяжении многих ветхозаветных поколений и завершившихся в естестве Самой Девы» (Arhiep. Grigorij Palama, 1965, s. 146). Причем надо подчеркнуть, что эти очищения совершались не механически и принудительно, но с соблюдением свободы как самой Девы Марии, так и ее предков.

Итак, подводя итог, можно сказать, что, выражением «от человек прозябшую» преп. Иоанн Дамаскин хотел выразить мысль о том, что Пресвятая Богородица явила Собой итог и плод всей ветхозаветной педагогической подготовки человечества к принятию воплощенного Бога. Эту мысль святой отец очень хорошо выразил в слове на Успение Пресвятой Богородицы: «Такого существа (Пресвятой Богородицы - прот. В. П.) никогда раньше не было и тоже никогда снова не будет... Она нашему нынешнему житию подаренный дар, больший и любезнейший от всех Божиих даров» (Prep. Ioann Damaskin, 1997, s. 261 - 274).

Но возникает логический вопрос, почему при работе над богослужебными книгами переводчики оставили именно слово «прозябшую»? Чтобы ответить на этот вопрос, надо понимать, что перевод Библии и других богослужебных текстов значительно отличается от перевода любого другого текста. Каждый переводчик при работе над текстом сталкивается, по крайней мере, с двумя главными проблемами. Во-первых, проблемой филологической, когда требуется сохранить точность перевода. И, во-вторых, проблемой богословской, когда требуется максимально близко и правильно передать мысль автора. Эту проблему правильно и точно определила в своей работе священник Георгий Кочетков: «Конечно, все переводы богослужебных текстов должны быть филологически достаточно выверенными и точными, но прежде всего они должны быть богословски адекватными» (Kočetkov, 2007, s.7). Как мы видим, выбор переводчиками слова «прозябшую» был «богословски адекватным». Ведь через слово «прозябшую» ум молящегося человека отсылается к ветхозаветной истории с прозябшим жезлом Аарона, как прообразу Девы Марии. Напомню, что в христианской экзегетике чудесно процветший жезл Аарона всегда считался прообразом Пресвятой Богородицы и в этом качестве часто встречается в иконографии, в миниатюрах, монументальной живописи и иконах. «Ныне Адам приносит от нас и за нас начатки Богу, достойнейший плод человечества - Марию, - говорит свт. Андрей Критский - в Которой (Новый Адам) делается Хлебом для восстановления человеческого рода... Ныне - по пророчеству - произрасла Отрасль Давидова, Которая, став вечно зеленеющим Жезлом Аарона, процвела нам Жезл Силы - Христа. Ныне от Иуды и Давида происходит Дева Отроковица, изображая Собою царское и священническое достоинство Принявшего (священство) Аарона по чину Мелхиседекову. Ныне благодать, убелив таинственный ефуд божественнаго священства, соделала его из левитскаго семени, и Бог украсил царскую порфиру кровию Давида» (Izbrannyâ slova svâtyh otcev v čest' i Slavupresvâtoj Bogorodicy, 1869, s. 44). Более очевидно мы можем увидеть это в богослужебных текстах. Например, «ныне жезл Ааронов, от корене Давидова прозябший, ныне Дева Чистая происходит, и сликовствует Небо и земля, и вся отечествия языков, и Анна и Иоаким таинственно» (Mineâ, sentâbr', 1997, s. 241), «от суха прозябение жезла иереева Израилю показа проразсуждение, и ныне светлость прозябших преславно светит, от неплодове всеславное рождение» (Mineâ, sentâbr', 1997, s. 242), «днесь да веселятся ангельстии чини, песньми да ликуют сущии из Адама: родися бо жезл, Цвет возрастивший, Христа, Единаго Избавителя нашего» (Mineâ, sentâbr', 1997, s. 242) и т.д.

Надо заметить, что сам преп. Иоанн Дамаскин в 4-ой книге «Точное изложение Православной веры» в главе под названием «О родословии Господа и о Святой Богородице», толкуя обращенные к царю Давиду слова Господа: «от плода чрева твоего посажу на престоле твоем» (Пс 131: 11), употребляет

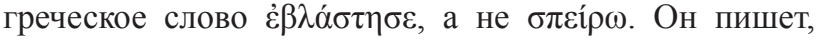
что «Она (Дева Мария - прот. В. П.), предопределенная предвечным и предузнающим советом Божи- 
им и через Святого Духа как представленная, так и предвозвещенная различными образами и словами пророков, в предназначенное время прозябла от племени Давида, вследствие бывших по отношению к нему обетовании» (Prep. Ioann Damaskin,2000, s. 298)

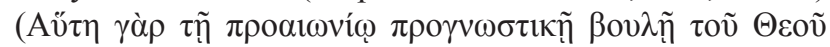

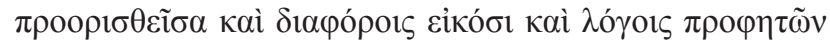

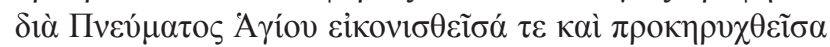

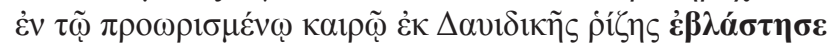

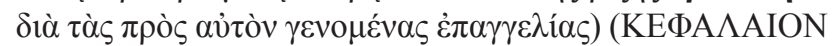

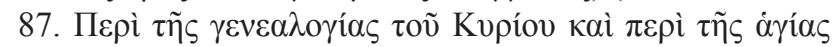

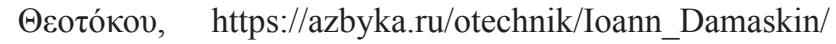
ekdosis-akribes-tes-orthodoxou-pisteos/4, 26.03.2019).

Это, на первый взгляд, кажущееся противоречие можно объяснить тем, что центральной Личностью, о Которой ведет рассуждение преп. Иоанн Дамаскин в 14 (87) главе своей книги, является Иисус Христос, а не Дева Мария. История Его земного происхождения, описание Его родословной - это главные темы, которые раскрываются через описание тех событий, которые связанны с личностью Пресвятой Богородицы. Фигура Пресвятой Богородицы как бы вплетается в рассуждения о происхождении Христа. Как точно сказал епископ Афанасий (Евтич): «Учение о Пресвятой Богородице (преп. Иоанна Дамаскина - прот. В. П.) существует только внутри христологии, а не как некоторая самостоятельная мариология или как некоторая особая антропология, имеющая центром Святую Деву» (Ierom. Afanasij(Ievtič), 1971, s. 41). Эту же мысль мы находим и у прот. Георгия Флоровского: «Мариология - не самостоятельное учение, а лишь глава в трактате о Воплощении. Но, конечно, не случайная глава, не приложение, без которого можно обойтись. Она входит в самую сущность учения. Тайна Воплощения немыслима без Матери Воплощенного» (Florovskij, 2000, s. 256). Преп. Иоанн не мог объяснить земное происхождение Иисуса Христа без описания Его родословной, которая представляет собой последовательную смену поколений людей. Вот поэтому автор использует слово

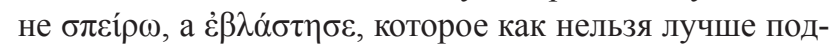
ходит для раскрытия этой темы.

Продолжая раскрывать личность Девы Марии, автор догматика именует Ее «небесной дверью» (

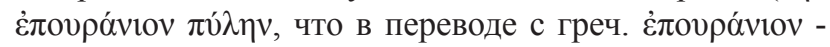

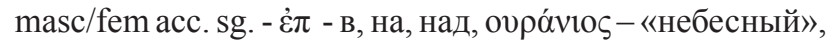

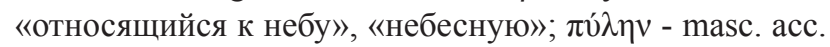
sg. - «ворота») (Vejsman, 1899, s. 520).

Событие рождества Пресвятой Богородицы имеет огромное значение для всей мировой истории человечества. По справедливому утверждению преп. Иоанна Дамаскина: «Праведно и воистину святую Марию называем Богородицей, ибо это имя составляет все таинство домостроительства» (Prep. Ioann Damaskin, 2000 , s. 222). И это действительно так, ведь вся история Ветхого Завета сводилась к одному - подготовить народ Израиля к достойной встрече своего Мессии, сохранить и пронести через все человеческие поколения мысль о том, что когда-нибудь наступит время, и Мессия, потомок Давида, Помазанник Божий явит, наконец, Себя миру и разрешит эпоху Ветхого Завета. Вот как об этом пишет профессор В. Н. Лосский: «Послушание Ноя, жертвоприношение Авраама, исход народа Божия под водительством Моисея через пустыню, Закон, пророки, ряд божественных избраний, при которых люди то пребывают верными обетованию, то падают и подвергаются наказаниям (пленение, разрушение первого храма), - все священное предание евреев есть история медленного и трудного продвижения падшего человечества по пути к «полноте времен», когда ангел будет послан, чтобы благовествовать избранной Деве Воплощение Бога и получить из Ее уст человеческое согласие на совершение божественного Домостроительства спасения» (Losskij, 1995, s. 72). Но Господь никогда не насилует свободу и волю человека. Он наоборот дает человеку мышление, чтобы он сам сделал выбор и пожал плоды этого выбора. Встреча человека с Богом, что на личном уровне, что на уровне всего общества, это всегда соединение двух воль, симфония воли земной или человека и воли Божественной. Как говорит преп. Иоанн Дамаскин: «Это Домостроительство Божие, подготавливавшее человеческие условия Воплощения Сына Божия, - действие не одностороннее. Божественная воля не уничтожает истории человечества. В своем Домостроительстве спасения Премудрость Божия сообразуется с колебаниями воли людей, с ответами людей на Божий призыв. Так в поколениях ветхозаветных праведников созидает Она Себе дом, чистейшую природу Пресвятой Девы, через Которую Слово Божие сделается единосущным нам» (Prep. Ioann Damaskin,2000, s. 223).

И поэтому, как только человечество принесло Богу это чистейшее и смиреннейшее существо, или, как далее в догматике мы называем Пресвятую Богородицу, принесло «верных украшение» (в переводе со славянского языка «удобрение» означает «украшение») (D'âčenko, 1993, s. 751), состоялся и сам факт Боговоплощения. Говоря другими словами, Рождество Пресвятой Богородицы - это начало нашего спасения, это дверь нашего спасения: «Днесь неплодная врата отверзаются и дверь девическая Божественная предгрядет, Днесь плод раждати благодать начинает, являющи миру Божию Матерь, Еюже земная с Небесными совокупляются, во спасение душ наших» (Mineâ, sentâbr', 1997,s. 233).

Боле того, мы можем найти тесную связь и параллель между выражением «небесная дверь ( книгой пророка Иезекииля. В 44 главе пророк говорит: «И привел он меня обратно ко внешним воротам ( $\left.\pi v^{\lambda} \eta \varsigma\right)$ святилища, обращенным лицом на восток, и они были затворены. И сказал мне Господь: ворота сии будут затворены, не отворятся, и никакой человек не войдет ими, ибо Господь, Бог Израилев, вошел ими, и они будут затворены. Что до князя, он, [как] князь, сядет в них, чтобы есть хлеб пред Господом; войдет путем притвора этих ворот, и тем же путем выйдет. Потом привел меня путем ворот северных перед лице 
храма, и я видел, и вот, слава Господа наполняла дом Господа, и пал я на лице мое» (Иез. 44; 1-4). «Кого же, как не Марию обозначают эти врата? - говорит свт. Амвросий Медиоланский, - Они заперты, потому что она - дева. Итак, врата обозначают Марию, чрез которую Христос вошел в этот мир, явившись от девственного рождения и не повредив ключей девства» (Svt. Amvrosijmediolanskij, 1901, s. 185). Как мы видим из толкования свт. Амвросия, в таинственном смысле врата святилища - это прообраз Девы Марии, через Которую в мир вступает Живой Бог. Подобная мысль сохраняется и в богослужебных текстах: «Аще и Божественным хотением светлыя неплодны жены прозябоша, но всех Мария рожденных боголепно превозсия: яко, от неплодныя преславно рождшися матере, породи плотию всех Бога, паче естества от безсеменныя утробы; едина дверь Единороднаго Сына Божия, юже прошед, заключенну сохрани и, вся мудре устроив, яко весть Сам, всем человеком спасение содела» (Mineâ, sentâbr', 1997, s. 232).

\section{3 Богословско-экзегетический разбор второй части догматика}

«Сия бо явися

Небо и храм Божества;

Сия преграждение

Вражды разрушивши,

Мир введе

И царствие отверзе,

Сию убо имуще

Веры утверждение,

Поборника имамы

Из нея рождшагося Господа».

Как мы видим, вторая часть догматика насыщена яркими образами и метафорами, которые делают этот текст более ярким и эмоциональным. Такой литературный прием подчеркивает, какую важную роль в деле нашего спасения занимает Дева Мария.

С первых строк второй части преп. Иоанн Дамас-

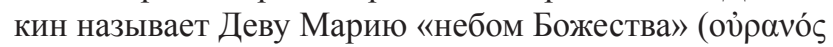
$\tau \tilde{\eta} \varsigma \Theta \varepsilon o ́ \tau \eta \tau о \zeta)$.

Такое сравнение мы очень часто встречаем и в богослужебных текстах. Например, «Ангеловым проречением плод пречист от Иоакима и Анны, праведников, Днесь произыде Дева, небо и престол Божий, и приятелище Чистоты, радость провозвещающи всему миру, живота нашего Ходатаица, клятвы отъятие, благословения подание. Тем в рождестве Твоем, Дево Богозванная, миру мир испроси и душам нашим велию милость» (Mineâ, sentâbr', 1997, s. 236), «Да радуется Небо, и земля да веселится: Божие бо небо на земли родися, Богоневестная Сия, от обетования. Неплоды Младенца доит Марию, и радуется о рождестве Иоаким: жезл, глаголя, родися мне, из негоже Цвет Христос прозябе, из корене Давидова. Воистину чудо преславно!» (Mineâ, sentâbr', 1997, s. 236) и т.д.
Слово «небо» (небеса) очень часто встречается и в книгах Священного Писания, но в своем употреблении имеет несколько лексических значений. Например, слово «небо» может употребляться в Священном Писании, когда речь идет о видимом небе, которое мы видим глазами. Например, «Он же сказал им в ответ: вечером вы говорите: «будет вёдро, потому что небо красно»; и поутру: «сегодня ненастье, потому что небо багрово» (Матф. 16: 2), «И вывел его вон и сказал: посмотри на небо и сосчитай звезды, если ты можешь счесть их. И сказал ему: столько будет у тебя потомков» (Быт. 15: 5).

В первом стихе книги Бытие мы встречаем слово «небо» в значении «вся Вселенная»: «В начале сотворил Бог небо и землю» (Быт. 1: 1). В понимании древних людей, видимое небо представлялось как опрокинутая чаша, которая своими краями касалась земли и таким образом замыкала всю Вселенную. Это дало повод Господу Иисусу Христу употребить такие выражения, как «и пошлет Ангелов Своих с трубою громогласною, и соберут избранных Его от четырех ветров, от края небес до края их» (Мф. 24: 31), «и тогда Он пошлет Ангелов Своих и соберет избранных Своих от четырех ветров, от края земли до края неба» (Мк. 13: 27).

Но слово «небо» в Священном Писании встречается и в значении «место обитания Бога». Например, Соломон молился Богу при посвящении храма: «Господи, Боже Израилев! Нет подобного Тебе Бога на небесах вверху и на земле внизу... Поистине, Богу ли жить на земле? Небо и небо небес не вмещают Тебя, тем менее сей храм, который я построил» (3 Цар. 8: 23 - 27; ср. с 2 Пар. 2: 6; 6: 18). Священное Писание совершенно ясно и неоднократно утверждают, что Бог обитает на небе: «С небес призирает Господь, видит всех сынов человеческих; с престола, на котором восседает, Он призирает на всех, живущих на земле» (Пс. 32: 13 - 14). Когда народ молится в направлении храма, Бог слышит на небе, месте Своего обитания, и прощает его: «Услышь моление раба Твоего и народа Твоего, Израиля, когда они будут молиться на месте сем; услышь на месте обитания Твоего, на небесах, услышь и помилуй» (3 Цар. 8: 30). Во времена царя Езекии «встали священники и левиты, и благословили народ; и услышан был голос их, и взошла молитва их в святое жилище Его на небеса» (2 Пар. 30: 27). Псалмопевец говорит: «Господь во святом храме Своем, Господь, - престол Его на небесах» (Пс. 10: 4), «Господь на небесах поставил престол Свой, и царство Его всем обладает» (Пс. 102: 19). Иисус Христос за время Своего общественного служения часто говорил о Боге, как о Небесном Отце: «Так да светит свет ваш пред людьми, чтобы они видели ваши добрые дела и прославляли Отца вашего Небесного» (Мф. 5: 16), «да будете сынами Отца вашего Небесного, ибо Он повелевает солнцу Своему восходить над злыми и добрыми и посылает дождь на праведных и неправедных» (Мф. 5: 45) и т.д. Во всех приведенных цитат под словом «небо» подразумевается место обитания Бога. Небо - это жилище и обитель Бога, которое 
апостол Павел называет «третьим небом» или «раем» (2 Kop. 12: 2, 3).

Однако, является ли небо буквальным местом обитания Бога? Этот вопрос снова проясняет мудрый царь Соломон: «Поистине, Богу ли жить с человеками на земле? Если небо и небеса небес не вмещают Тебя, тем менее храм сей, который построил я» (2 Пар. 6: 18). Поэтому в Священном Писании есть цитаты, в которых под словом «небо» подразумевается не только место обитания Бога и нахождения Его престола, но большее - небо и есть Сам Его престол, символ Его власти: «Так говорит Господь: небо - престол Мой, а земля - подножие ног Моих; где же построите вы дом для Меня, и где место покоя Моего?» (Ис. 66: 1).

Как мы видим, Бог в буквальном смысле этого слова не живет в материальной Вселенной, которую Он сотворил. Бог находится за пределами материальной Вселенной. Но тогда возникает логический вопрос: что подразумевается под словом «небо» как месте обитания Бога? Все станет на свои места, если вспомнить, что «Бог есть дух» (Ин. 4: 24). Если Бог - это духовная личность, то и небеса, в которых Он обитает - это духовная сфера жизни, неподвластная человеческому мышлению. Вот поэтому после возвращения из вавилонского плена иудеи стали использовать слово «небо» как синоним слова «Бог». В Новом Завете это явление также встречается достаточно часто. Например, в притче о блудном сыне вернувшийся домой сын говорит отцу: «Я согрешил против неба и пред тобою» (Лк. 15: 18). Здесь, как мы видим, происходит как бы олицетворение неба. Грех блудного сына был направлен против Бога. Свт. Филарет Дроздов в своем толковании говорит: «Вошед в себя, он (блудный сын прот. В. П.) яснее сознает, чего требует душа его, и как многаго ей недостает; воспоминает Отца небеснаго, и блага, которых лишился чрез удаление от Него; и решается возвратиться к Нему, т.е. оставить жизнь греховную и жить по заповедям Божиим» (Svt. Filaret Drozdov,1885, s. 463). Подобным образом и с таким значением употребляет слово «небо» в Своей речи и Иисус Христос, когда говорит: «Клянущийся небом клянется Престолом Божиим и Сидящим на нем» (Мф. 23: 22). Здесь Бог представлен в символе места Своего обитания.

Таким образом, называя Деву Марию «небом Божества», автор подчеркивает, что Она стала вместилищем Самого Бога. За всю историю человечества Она стала единственным в истории мира человеком, в Которую вселился Сам Творец мира, Которая вместила в себя Невместимого. Как точно замечает преп. Ефрем Сирин: «Мария соделалась для нас небом - Божиим престолом, потому что в Нее низошло и в Ней вселилось высочайшее Божество. Чтобы нас возвеличить, умалилось в Ней Божество, не умаляясь, впрочем, в естестве Своем. В Ней облеклось Оно в ризу для нас же, чтобы нам доставить Ею спасение» (Prep. Efrem Sirin, 1912,s. 166).
Более того, образ Девы Марии как неба отсылает нас к первым главам книги Бытие. На заре человеческой истории в райском саду произошла драма, которую сам автор догматика описывает следующим образом: «Итак, когда все люди - скажу кратко - подверглись тлению, тогда милосердый Бог, не желая, чтобы уничтожилось создание рук Его, творит другое новое небо, землю и море, в которых Невместимый благоволил вместиться для возсоздания рода человеческого. Это - блаженная и преславная Дева. О чудо! Она есть небо, потому что из неприступных сокровищ изводит солнце правды» (Prep. Ioanna Damaskina,1997, s. 249).

Вот поэтому в своем обращении к Божьей Матери мы дерзаем называть Ее «небом», т.е. местом пребывания Бога или «храмом», как телесно вместившую Божество. «Как изображу я Твою величавую поступь? Как одеяние? Как исполненное приязни лицо? - вопрошает св. Иоанн Дамаскин. - [У Тебя] старческий ум в младенческом теле. Одежда [у Тебя] скромная, избегающая роскоши и неги; поступь величавая, спокойная, чуждая вялости. Нрав строгий, но соединенный с радушием... слова кроткие, исходящие из незлобивой души. Что же иное [можно заключить], как не то, что Ты - достойное жилище Бога» (Prep. Ioanna Damaskina, 1997, s. 259).

Надо отметить, что в догматике на месте слова «храм» стоит греческое слово vaós.

Обычно в Новом Завете для обозначения Иерусалимского храма употребляется другое греческое слово - iєро́v, что буквально означает «святилище» (Vejsman, 1899, s. 623). Например, «потом берет Его диавол в святой город и поставляет Его на крыле храма (iєрóv)» (Мф. 4; 5), «или не читали ли вы в законе, что в субботы священники в храме (iєрóv) нарушают субботу, однако невиновны?» (Мф. 12; 5). Греческое же слово vaós чаще используется для выражения мысли о теле, как храме души. Например, «Иисус сказал им в ответ:

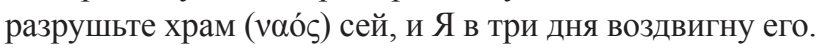
На это сказали Иудеи: сей храм строился сорок шесть лет, и Ты в три дня воздвигнешь его? А Он говорил о храме тела Своего ( 2: 19-21), «разве не знаете, что вы храм (vхós) Божий, и Дух Божий живет в вас? - пишет апостол Павел. - Если кто разорит храм ( $\tau o v$ vaóv) Божий, того покарает Бог: ибо храм (о vaós) Божий свят; а этот храм - вы» (1 Кор 3: 16-17). Можно привести и другие цитаты со словом vaós, но везде будет прослеживаться мысль о том, что наше тело - это храм для души, а храм, как сказал Господь, осквернять нельзя. Поэтому, когда преп. Иоанн говорит, что Пресвятая Богородица - это «храм Божества», то здесь подчеркивается мысль о том, что Она телесно вместила в себя Господа Иисуса Христа. Ее тело - это храм (в значении voó ) для Премудрости Божией.

Когда же мы говорим о православных храмах, то здесь мы употребляем греческое слово оі̃коц. Например, когда на мирной ектение мы призываем молящихся

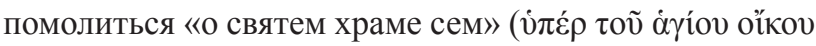

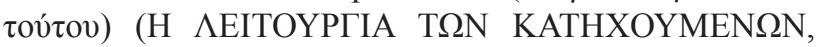


https://azbyka.ru/otechnik/greek/liturgija-svt-ioannazlatousta-na-grecheskom-i-tserkovnoslavjanskomjazykah/, 28. 03. 2019), то мы молимся о святом доме (оі̃ко - дом, жилище, (иногда) комната) (Вейсман, 1899 , с. 869), в котором христиане собрались на молитву и совершения Таинства Евхаристии. Т.е. здесь подчеркивается мысль, что православный храм, как собственно здание, не является местом исключительного пребывания Божества. Для нас христиан православный храм - это особое место, где совершается Таинство Евхаристии. Есть храм - есть и Евхаристии. Поэтому, молитва «о святем храме сем» - это молитва-просьба к Богу не лишить нас этой возможности собираться здесь, в этом святом месте.

Теперь разберем выражение «Сия преграждение вражды разрушивши, мир введе и Царствие отверзе».

Слово «вражда» на страницах Священного Писания впервые встречается в 3 - ей главе книги Бытие: «И вражду положу между тобою и между женою, и между семенем твоим и между семенем ее; оно будет поражать тебя в голову, а ты будешь жалить его в пяту» (Быт. 3, 15). Эти слова были обращены Богом к змею, который соблазнил первых людей в Эдемском саду. В результате бесовского искушения в Эдеме произошла катастрофа, которая кардинальным образом изменила отношения первых людей с Богом Творцом, с окружающим миром, отношения между собой и внутреннее состояние каждого из них в отдельности. В конечном итоге, все это привело к тому, что «праотцы, оказав преслушание Богу и склонившись в послушание диаволу, сами себя сделали чуждыми Бога, сами себя сделали рабами диавола» (Еp. Ignatij Kavkazskij, 1995, s. 307). Но именно в словах Бога к змею - «и вражду положу между тобою и между женою, и между семенем твоим и между семенем ее» - Православная Церковь видит прикровенное указание на приход в мир Спасителя, Который разрушит власть греха и смерти. Ведь здесь надо обратить внимание на то, что когда Бог обещает положить вражду между добром и злом, то Он говорит о семени жены, а не мужа, хотя согласно Библейской логики важно именно семя отца (мужчины). Т.е. перед нами пророчество о девстве Пресвятой Богородицы - Победитель обязательно родится от жены, но семя мужа в этом не примет участия. И это пророчество сбылось более двух тысяч лет назад, когда Дева Мария услышала от ангела дивные слова: «Не бойся, Мария, ибо Ты обрела благодать у Бога; и вот, зачнешь во чреве, и родишь Сына, и наречешь Ему имя: Иисус» (Лк. 1: 30).

Вот о разрушении какой преграды и вражды говорится в словах догматика «сия преграждение вражды разрушивши, мир введе и Царствие отверзе». Этого светлого и радостного события ожидал не только народ избранный - Израиль, но и все человечество, которое со времен прародителей Адама и Евы, подчас неясно, подспудно, но все-таки помнило Божие обетование о приходе в мир Спасителя. Эту же мысль мы находим и у апостола Павла: «Ибо Он есть мир наш, соделавший из обоих одно и разрушивший стоявшую посреди пре- граду, упразднив вражду Плотию Своею» (Еф. 2; $14-$ 15). Блаж. Феофилакт Болгарский объясняя эти стихи говорит: «В чем состояла преграда: во вражде к Богу и язычников, и иудеев, - во вражде, которая происходила, от наших преступлений, как и пророк говорит: беззакония ваши произвели разделение между вами и Богом (Ис. 59: 2)» (Svt. Feofilakt Bolgarskij, 2009, s. 8).

Наконец, преп. Иоанн Дамаскин в своем догматике говорит о Богородице как об «утверждении веры» или буквально, в переводе с греческого, «якоре» нашей веры

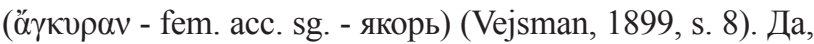
действительно, по справедливому замечанию прот. Георгия Флоровского, «всё догматическое учение о Владычице нашей выражено в двух Ее именах: Богородица и Приснодева. Оба имени получили кафолическое признание, оба приняты Вселенской Церковью» (Florovskij, 2000 , s. 238). Свт. Григорий Богослов говорит еще принципиальней: «Кто не исповедует Марию Богородицей, тот чужд Богу» (Florovskij, 2000, s. 247). Божья Матерь занимает совершенно особое место в сонме святых. Церковь именует Ее «честнейшую херувим и славнейшую без сравнения серафим», т.к. Она превосходит своей святостью не только человека, но и ангельский духовный мир. Ведь, кто может ближе к человеку, чем мать? Кто может любить больше, чем мать? Кто будет больше переживать, чем мать? Никто. Все мы являемся детьми Отца небесного, но ведь Бог то стал человеком и родился как человек из утробы Девы Марии. По человеческой природе Она Его мать, и Он Ее сын. Но во Христе невозможно отделить божественное от человеческого. Согласно Халкидонскому догмату, божество и человечество во Христе нераздельно, неразлучно, непреложно и неизменно. Поэтому, будучи самой близкой ко Христу, как к Своему Сыну, Она стала и самой близкой к Богу, Который был в Нем, и Которым Он был.

С другой стороны, любой моряк знает, что якорь - это всегда стабильность, покой и безопасность. И поэтому, называя Богородицу «якорем» (по-славянски, «утверждением») (D'âčenko, 1993, s. 765), перед глазами встает образ Божией Матери, именуемый как Отрада и утешение. Перед этим образом мы обращаемся к Деве Марии и в горе, и в радости, со всеми без исключения вопросами и проблемами, т.к. кто, как не Она, Богородица, является нашей гаванью и пристанью, где каждый из нас всегда найдет отраду и утешение.

Обратим внимание еще на одно греческое слово, употребленное в догматике. Это ное на церковнославянский язык как «Поборник», а на русский - как «Защитник». Эта лексема встречается и в другом, не менее известном, богослужебном тексте, однако там она передана по-славянски несколько менее вразумительно, хотя, возможно, и более привычно, - Великий акафист, который начинается со слова «Взбранной Воеводе победительная» (Ти̃ نं $\varepsilon \rho \mu \alpha ́ \chi \omega ~ \sigma \tau \rho \alpha \tau \eta \gamma \tilde{~}$

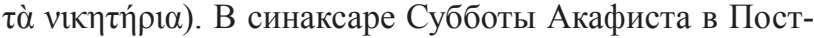
ной Триоди говорится, что этот кондак был исполнен в Константинополе 7 августа 626 г. как благодарственная песнь Богородице за избавление от нашествия ино- 
племенников (аваров) (Ksanfopul, 2017, s. 54). Строго говоря, такое значение имеет только 1-й кондак, в котором Богородица воспевается как «Взбранная воевода», т.е. военачальница (воевода), всех превосходящая в бранях. Слово «взбранная» или «возбранная» (греч.

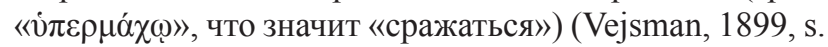
1281) происходит от слова «брань», а никак не от слова «выбор» или «избрание», как превратно перетолковывается это слово в некоторых других акафистах.

\section{4 Богословско-экзегетический разбор третьей части догматика}

Догматик заканчивается призывом, способным укрепить ослабевших, а потерявшим надежду на спасение возвратить упование на помощь Божью: «Дерзайте («дерзайте» в переводе со славянского «не бойтесь», «говорите и делайте смело» (D'âčenko, 1993, s. 142), такой же смысл сохраняется и в греческом тексте) убо, дерзайте, людие Божии, ибо Той победит враги, яко Всесилен».

Наверно эти слова воспримутся совсем по-другому, если вспомнить, что время жизни преподобного Иоанна Дамаскина - это время распространения ереси иконоборчества, поддерживаемой императором Львом III Исавром. Ересь иконоборчества - это не просто спор и некое недопонимание в терминах, это была настоящая война. Доходило до того, что самые ретивые и жестокие иконоборцы разрушали монастыри, казнили монахов. Поэтому, догматик преп. Иоанна Дамаскина по праву можно назвать и жемчужиной богослужеб- ного творчества, и настоящим воззванием к защите и проповеди православной веры.

\section{3. Заключение}

По словам свт. Афанасия (Сахарова), «в богослужении, в Уставе Православной Церкви нет ничего случайного, в нем все строго продумано. И все, даже малейшие детали имеют свой, часто весьма глубокий смысл, сообщают отдельным чинам и последованиям свой колорит, придают им особую умилительность и трогательность... Наше богослужение - высокохудожественное произведение, сложный механизм тонкой работы... И если иногда нам неясен смысл той или иной детали богослужения, - это не значит, что его вовсе нет... Это значит только, что мы пока еще не умеем понять его, не знаем. Надо найти его и постараться уяснить себе...» (Svt. Afanasij Saharov,1999, s. 22 - 26).

Поэтому, подводя итог всем рассуждениям, однозначно можно сказать, что воскресные догматики прп. Иоанна Дамаскина благодаря своей поэтической форме и стилю, особенностям построения, а главное, благодаря своему содержанию подтверждают мысль о том, что наша церковная гимнография - это храмовое исповедание наших церковных догматов, нашего вероучения и нравоучения, а при внимательном слушании и изучении этих глубоко-догматичных песнопений каждый христианин во время богослужения имеет возможность посвятить себя в таинственные глубины нашей веры.

\section{Bibliografia}

Bibliâ. Svâsennoe Pisanie Vethogo i Novogo Zaveta. (1992.). Moskva: Izdanie Moskovskoj Patriarhii. [Библия. Священное Писание Ветхого и Нового Завета. (1992.). Москва: Издание Московской Патриархии].

Amvrosij Mediolanskij, svt. (1901). O vospitanii Devy i Prisnodevstvesvâtoj Marii k Evseviû, Kazan'. [Амвросий Медиоланский, свт. (1901). О воспитании Девы и Приснодевстве святой Марии к Евсевию, Казань].

Afanasij (Saharov), svt. (1999). O pominovenii usopših po Ustavupravoslavnoj Cerkvi, Sankt-Peterburg. [Афанасий (Caхаров), свт. (1999). О поминовении усопших по Уставу Православной Церкви, Санкт-Петербург].

Grigorij Palama, svt. (1965). Besedy (Omilii), Monreal': izdanie bratstva prep. Iova Počaevskogo. [Григорий Палама, свт. (1965). Беседы (Омилии), Монреаль: издание братства преп. Иова Почаевского].

Dimitrij (Rostovskij), svt. (1906). Žitie svâtyh, k. 4, Moskva, Sinodal'naâ tipografiâ. [Димитрий (Ростовский), свт. (1906). Житие святых, к. 4, Москва, Синодальная типография].

Efrem Sirin, prep. (1990). Tvoreniâ, Moskva. [Ефрем Сирин, преп. (1990). Творения, Москва].
Ignatij Brânčaninov, svt. (2001). Asketičeskie opyty, t. 2, Moskva. [Игнатий Брянчанинов, свт. (2001). Аскетические опыты, т. 2, Москва].

Ioann Damaskin, prep. (2000). Točnoe izloženie pravoslavnoj very, Moskva: «Lod'â». [Иоанн Дамаскин, преп. (2000). Точное изложение православной веры, Москва: «Лодья»]. Ioanna Damaskina, prep. (1997). Hristologičeskie i polemičeskietraktaty. Slova na bogorodičnye prazdniki, Moskva. [Иоанна Дамаскина, преп. (1997). Христологические и полемические трактаты. Слова на богородичные праздники, Москва].

Ignatij Kavkazskij, svt. (1995). Slovo o čeloveke, Sankt-Peterburg. [Игнатий Кавказский, свт. (1995). Слово о человеке, Санкт-Петербург].

Irinej Lionskij, svt. (1900). Tvoreniâ, Sankt-Peterburg. [Ириней Лионский, свт. (1900). Творения, Санкт-Петербург].

Nikifor Kallistksanfopul. (2017). Sinaksari Postnoj i Cvetnoj Triodi. Perevod s grečeskogo svâsennika M. Pokrovskogo, Svâto -Troickaâ Sergieva Lavra. [Никифор Каллист Ксанфопул. (2017). Синаксари Постной и Цветной Триоди. Перевод с греческого священника М. Покровского, Свято-Троицкая Сергиева Лавра]. 
Sinezij Kirenskij, mitr. (2012). Polnoe sobranie tvorenij, t. 1, Sankt-Peterburg: «Svoe izdatel'stvo». [Синезий Киренский, митр. (2012). Полное собрание творений, т.1, Санкт-Петербург: «Свое издательство»].

Feofilakt Bolgarskij, svt. (2009). Tolkovanie na Poslaniâ svâtogoapostola Pavla, t. 2, Sankt-Peterburg. [Феофилакт Болгарский, свт. (2009). Толкование на Послания святого апостола Павла, т. 2, Санкт-Петербург].

Filaret (Gumilevskij), svt. (1882). Istoričeskoe učenie ob Otcahcerkvi, t. 3, Sankt-Peterburg. [Филарет (Гумилевский), свт. (1882). Историческое учение об отцах Церкви, т. 3, Санкт-Петербург].

Filaret (Drozdov), svt. (1885). Slova i reči, t. 5, Moskva. [Филарет (Дроздов), свт. (1885). Слова и речи, т. 5, Москва].

Mineâ, dekabr'. (1997). Moskva: izd. «Pravilo very». [Минея, декабрь. (1997). Москва: изд. «Правило веры»].

Mineâ, sentâbr'. (1997). Moskva: izd.«Pravilo very». [Минея, сентябрь. (1997). Москва: изд. «Правило веры»].

Oktoih. (1981). Moskva: izd.Moskovskoj Patriarhii. [Октоих. (1981). Москва: изд. Московской Патриархии].

Postnaâ Triod'. (1992). Moskva: izd. Moskovskoj Patriarhii. [Постная Триодь. (1992). Москва: изд. Московской Патриархии].

Tipikon, (1992). Svâto-Troice-Sergievalavra. [Типикон, (1992). Свято-Троице-Сергиева Лавра].

Ignatiâ (Puzik), shimonahinâ. (2005). Cerkovny epesnotvorcy, Moskva. [Игнатия (Пузик), схимонахиня. (2005). Церковные песнотворцы, Москва].

Izbrannyâ slova svâtyh otcev v čest' i slavu Presvâtoj Bogorodicy. (1869). Sankt-Peterburg: izd. Russkogo na Afone Panteleimonova Monastyrâ. [Избранныя слова святых отцев в честь и славу Пресвятой Богородицы. (1869). Санкт-Петербург: изд. Русского на Афоне Пантелеимонова Монастыря].

Losskij V. N. (1995). Po obrazu i podobiû, Moskva: izd. Svâto
-Vladimirskogo bratstva. [Лосский В.Н.(1995). По образу и подобию, Москва: изд. Свято-Владимирского братства].

Florovskij G. V. (2000). Izbrannye bogoslovskie stat'i, Moskva: izdatel'stvo «Probel». [Флоровский Г. В. (2000). Избранные богословские статьи, Москва: издательство «Пробел»].

Šmeman A., protopresviter. (1993). Voskresnye besedy, č. 3, Moskva. [Шмеман А., протопресвитер. (1993). Воскресные беседы, ч. 3, Москва].

Afanasij (Ievtič), ierom. (1971). Učenie o Presvâtojbogorodice u sv. Ioanna Damaskina, Pariž: Pravoslavnaâ mysl', vyp. 14. [Афанасий (Иевтич), иером. (1971). Учение о Пресвятой Богородице у св. Иоанна Дамаскина, Париж: Православная мысль, вып. 14].

Vejsman A. D. (1900). Grečesko-russkij slovar', Sankt-Peterburg. [Вейсман А. Д. (1900). Греческо-русский словарь, Санкт-Петербург].

D'âčenko G., svâs. (1993). Polnyj cerkovno-slavânskij slovar', Moskva. [Дьяченко Г., свящ. (1993). Полный церковнославянский словарь, Москва].

Sedakov O. A. (2000). Slovar' trudnyh slov iz Bogosluženiâ, Moskva. [Седаков О. А. (2000). Словарь трудных слов из Богослужения, Москва].

API@MOI, https://azbyka.ru/biblia/UBS/index.htm?OT/Nu?17, 11.03.2019.

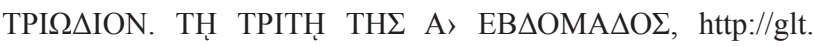
goarch.org/texts/Tri/t47.html, 12.03.2019.

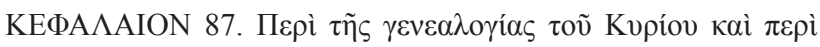

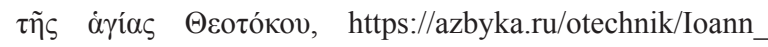
Damaskin/ekdosis-akribes-tes-orthodoxou-pisteos/4, 26.03.2019.

H $\Lambda$ ЕITOYРГІА T $\Omega \mathrm{N}$ KATHХOYMEN $\Omega \mathrm{N}$, https://azbyka. ru/otechnik/greek/liturgija-svt-ioanna-zlatousta-nagrecheskom-i-tserkovnoslavjanskom-jazykah/, 28.03.2019.

Rozmiar artykułu: 1,4 arkusza wydawniczego 